\title{
CAPITAL STRUCTURE OF MULTINATIONAL FIRMS AFTER THE GLOBAL FINANCIAL CRISIS
}

\author{
Janikan Supanvanij, St. Cloud State University, St. Cloud, Minnesota, U.S.A.
}

\author{
dx.doi.org/10.18374/JIBE-17-3.5
}

\begin{abstract}
The global financial crisis in 2007 has been the worst financial crisis after the Great Depression in 1930s. This study examines the financing behavior of S\&P multinational firms after the global financial crisis. The paper provides evidence that factors those appear to influence the capital structure during the normal economic condition may not significantly influence the financial structure after 2007. Results support that the economic downturn after the financial crisis has caused firms to rethink about their capital structure and financing decision.
\end{abstract}

Keywords: Capital Structure, Global Financial Crisis, International Involvement 